\title{
Anatomical Study of Vegetative Parts and Powder Microscopy of Cordia Myxa L. (Boraginaceae) In Iraq
}

\author{
Muazaz Azeez AL-Hadeethi, Aseel Kadhim Al-Anbari and Mazin Nwaf AL-Aani
}

\begin{abstract}
This study deals with the anatomical features of Cordia myxa stem, leaf and petiole in Iraq. Peeling method have been clarified anomocytic stomata with anticlinal walls of epidermal cells, the cross sections of lamina shown the unicellular epidermis in abaxial and adaxial surface, unicellular trichomes spread in the epidermis. adaxial covered by thick cuticle, bifacial mesophyll. idioblasts spread through palisade parenchyma, oval to circular shape cells of spongy parenchyma, midrib have large concentric vascular bundle is present at the midrib region and one vascular bundle in above. Petiole shape is square with five vascular bundle appear, the big one located on the central and four vascular bundle located in the corners. The dried leaf powder was brown to green in color, microscopy of the powder showed fragments of unicellular trichomes, stomata, fibers, crystal differ in shape like as regular prismatic, druses, sand crystal, and dendritic crystal like as snowflake formation in shape
\end{abstract}

Keywords--ordia myxa, Boraginaceae, Anatomical study, Powder microscopy.

\section{INTRODUCTION}

Cordia myxa L. belong to Boraginaceae family, it is a deciduous tree, and common names include Lasura, Assyrian, Spistan, Plum Pidar, Naruvilli and Ntege [1]. The genus Cordia including almost 250 species, occur in various Asian and African continents [2] and native to the Americas, [3].

C. myxa fruits is described in popular medicine as laxative and cough medicine in pulmonary diseases [4]. All the parts of this plant used as popular medicine when the stem bark of Cordia is used in traditional medicine for the treatment of gastric and respiratory disturbances [5]. In the Alagoas State, the leaves and flowers are used as treatment of hemorrhaging, throat infections and cold [6], also the leaves and roots of Cordia are used in folk medicine for digestive disturbances, rheumatism and as a generaltonic [7], besides the treatment of symptoms of menstrual colic and dyspepsia [8]-[9]-[10], so the leaves and stem of Cordia are used for various superficial inflammatory processes in wound areas and general inflammations and also as an analgesic for menstrual colic [11].

Muazaz Azeez Hasan is with the Department of Biology, College of education for pure sciences ( Ibn- Al- haitham), Baghdad University, IRAQ

Aseel Kadhim Hadi Al-Anbari is with the Department of Biology, College of education for pure sciences, Diyala University, IRAQ .

Mazin Nwaf AL-Aani is with the Department of Biology, College of education for pure sciences ( Ibn- Al- haitham), Baghdad University, IRAQ
The survey concluded that no anatomical studies were carried on this genus in Iraq or abroad. On other hand there are many taxonomicaland phytochemical studies on this plant and some members of Boraginaceae such as [12]-[13]-[14] studiesAnatomical study deals with the structure, contents and the systematic anatomy is mainly aimed towards relating structure particularly of vegetative organs to taxonomic classification of the plants, moreover the anatomical evidence can be employed in the identification [15], which may often be leaf epidermis and leaf cross section, anatomy provide extensive taxonomic data and the chemical compounds distribution in organs to isolate and used as a treatment. [16] Reported due the high cooperation between unique structures and medical importance we need to inspect anatomical characters.

The aim of this study to identify the internal anatomy of vegetative parts of this genus because its importance as a treatment popular for various pulmonary diseases, on the other hand absence studies of this genus and lack resources in Iraq.

\section{MATERIAL AND METHODS}

\section{A.Collection and authentication of plant material}

Cordia myxa plant was collected from the herbal garden at AL-Rashidia city north of Baghdad in the month of April 2016. The plant material was identified and authenticated by flora of Iraq 'Fig. 1'.

\section{B.Microscopically investigation}

The epidermis were prepared followed by washing with distilled water, put it in $10 \% \mathrm{KOH}$, then passed through alcohol for 10- 15 minute and then stained by $1 \%$ safranin for 30-45 minute. Excess stain was washed off with distilled water, dehydrated by ethanol series (70, 95, and 100\%) and cleared with pure xylene 10 minute. Finally, the epidermal samples were put on the slides and mounted by cover slides with Dextrin Plasticizer Xylene (D.P.X) artificial mounting medium. All permanent slides were examined by Olympus $\mathrm{BH} 2$ light microscope and photographed using Olympus $\mathrm{CH} 3$ camera. All prepared according to [17].

\section{C.Powder microscopy}

To a little quantity of finely ground plant powder taken on a microscopic slide, $1-2$ drops of $0.1 \%$ phloroglucinol solution was added along with a drop of concentrated $\mathrm{HCl}$. It was mounted in glycerol and observed under microscope. The characteristic features of the powder were noted. Analysis of powder microscopy of leaf was done by standard procedure as [18]. 


\section{RESULTS AND DISCUSSION}

Stomata shape: Stomata shape in Cordia myxa was anomocytic type, guard cells have kidney shape. The length of stomata is $25.3 \mu \mathrm{m}$ and the width is $17.2 \mu \mathrm{m}$ in adaxial surface and the length of stomata are $26.3 \mu \mathrm{m}$ and the width is 19.3 $\mu \mathrm{m}$ in abaxial surface. The anticlinal walls of epidermal cells were normally winding 'Fig. 2'. [1] was confirmed this truth which revealed that stomata in Cordia myxa are usually anomocytic type.

Cross Sections of Lamina: Upper epidermis has a single layer with thickness is $18.5 \mu \mathrm{m}$ covered by solid cuticle $1.5 \mu \mathrm{m}$ thickness. Mesophyll have been separated into upper palisade and lower spongy parenchyma that's mean the mesophyll are bifacial. Palisade parenchyma consists of two layers $25.5 \mu \mathrm{m}$ thickness, the idioblasts spread through it. Spongy parenchyma have numerous layers, oval to circular shape $215.5 \mu \mathrm{m}$ thickness. Lower epidermis which have a single layer with 9.5 $\mu \mathrm{m}$ thickness 'Fig. 3'. As well as spread many unicellular trichomes in the upper and lower epidermis of leaf 'Fig. 2'.

Midrib: Large concentric vascular bundles were presented at the midrib region and two vascular bundle was small in above, the large one look like a horseshoe and the other a cordial shape. Xylem and phloem with $240.5 \mu \mathrm{m}$ thickness. Xylem ring appears towards in the center and was surrounded by phloem ring. Sclerenchyma tissue occurs around the vascular tissues as bundle cup fiber and the pith central located 'Fig. 4'.

Transverse Sections of Petioles: Petioles square shape have one layer of circular epidermis cells, covered with cuticle of variable thickness, followed by a cortex have 2-3 rows of collenchyma. This layer spread around the vascular bundle region, the parenchyma layer consist of several rows (4-6 cells) and five vascular bundle appeared, the big one located on the central of petiole surrounded by perivascular fiber and four circular vascular bundle located in the corner 'Fig. 5'.

Powder microscopy: The dried leaf powder was brown to green in color. Microscopy of the powder detected the presence of fragments of unicellular trichomes, stomata, fibers, crystal differ in shape like as regular prismatic shapes, druses shapes, sand crystal shapes and dendritic crystal like as snowflake formation in shape, all the crystal in the plant cell mainly composed of calcium oxalate occur in two chemical forms monohydrate and dihydrate and both of these appear in plants, the monohydrate is more stabilized and is more commonly in plants than dihydrate [19]-[20], 'Fig. 6'.

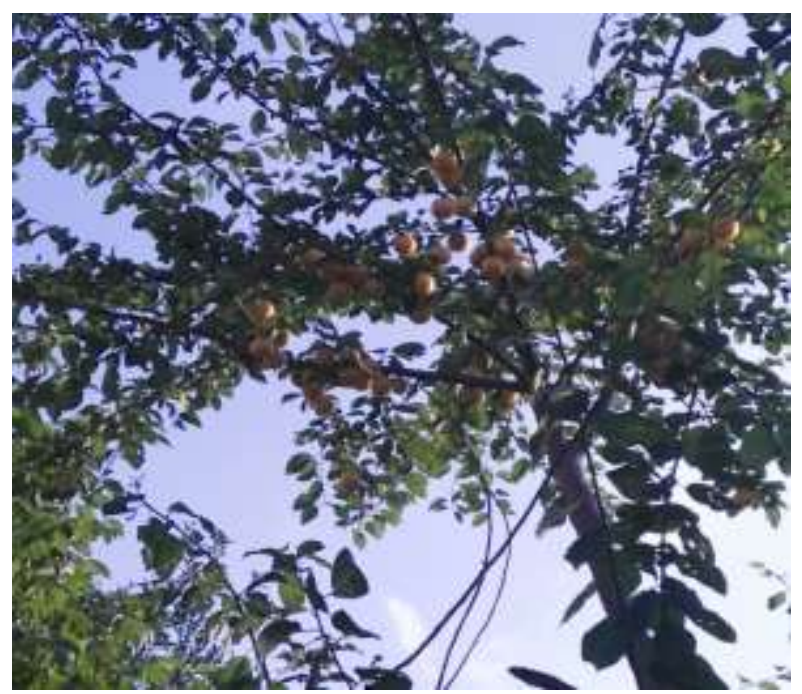

Fig.1 Shape of the Cordia myxa tree.

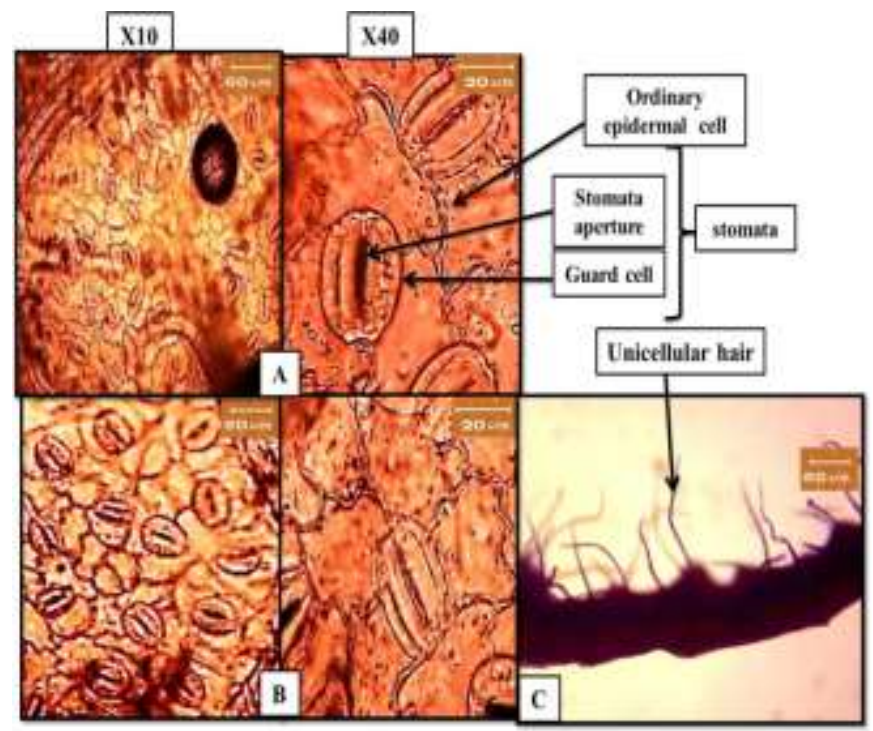

Fig. 2 Surface view of epidermal cells, stomata, trichomes in leaves of Cordia myxa, A. upper epidermis, B. lower epidermis appear in 10X and $40 \mathrm{X}$ and $\mathrm{C}$ : unicellular trichomes.

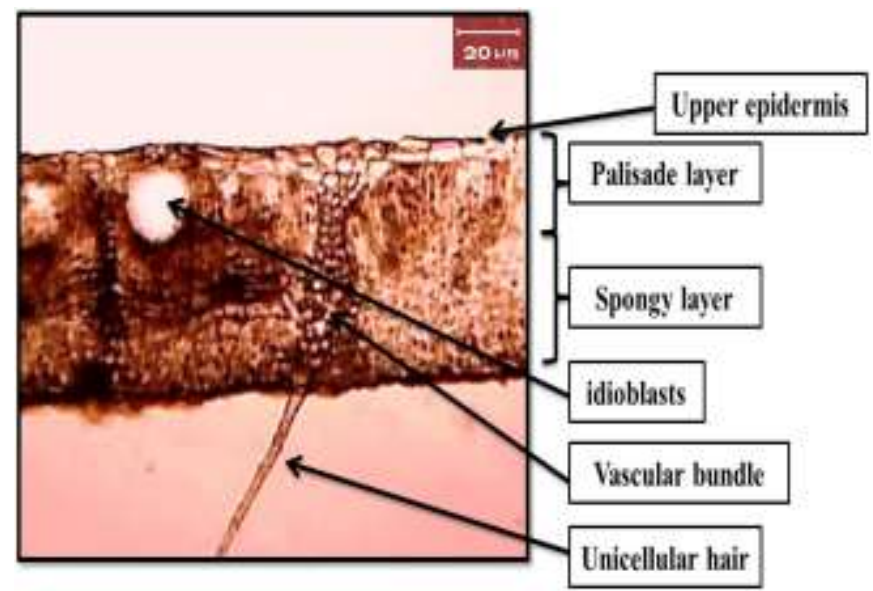

Fig. 3 Cross section of blade in leaf of Cordia myxa. 


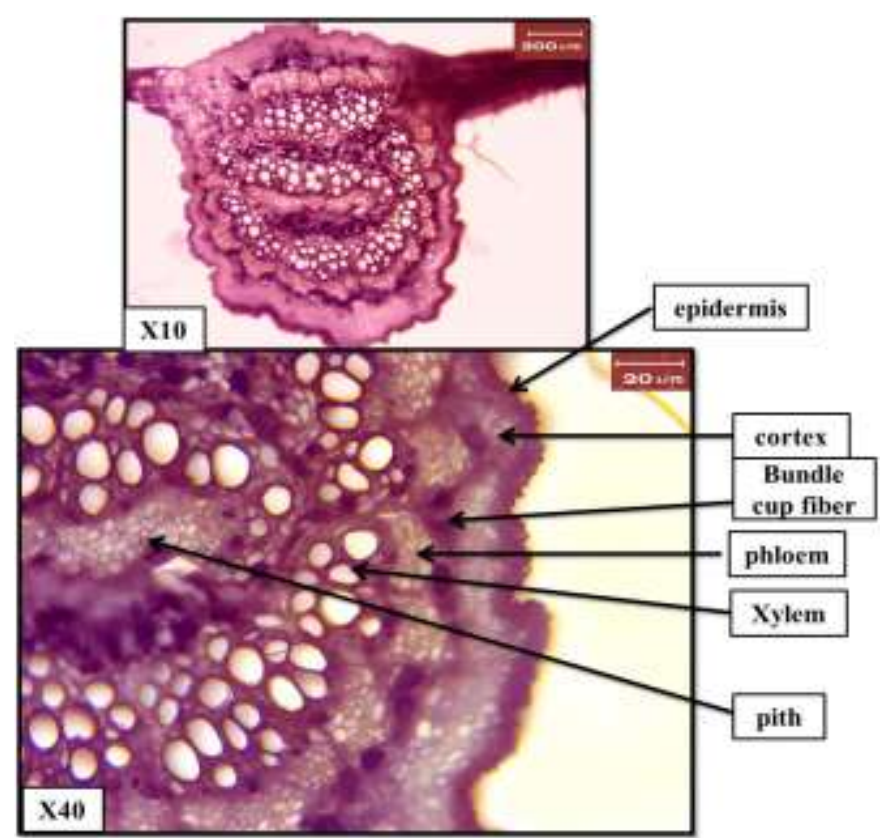

Fig. 4 Cross section of midrib in leaf of Cordia myxa.

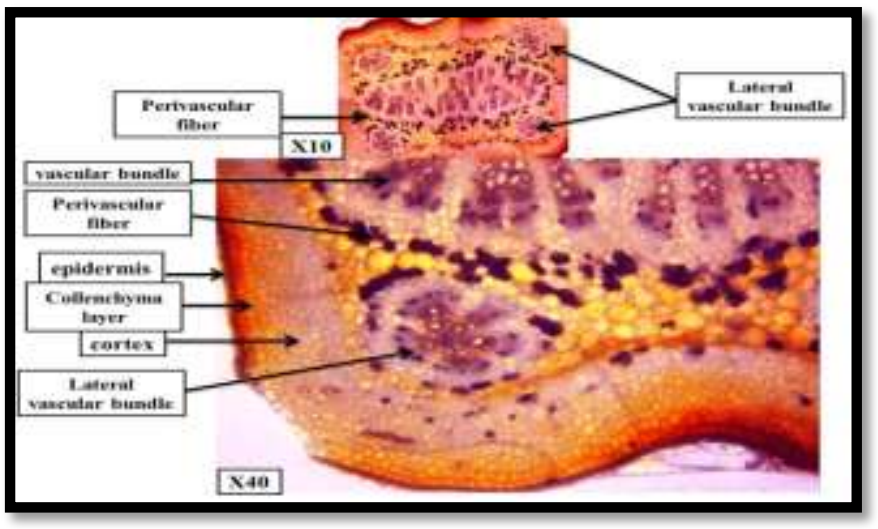

Fig. 5 Cross section of petiole in leaf of Cordia myxa.

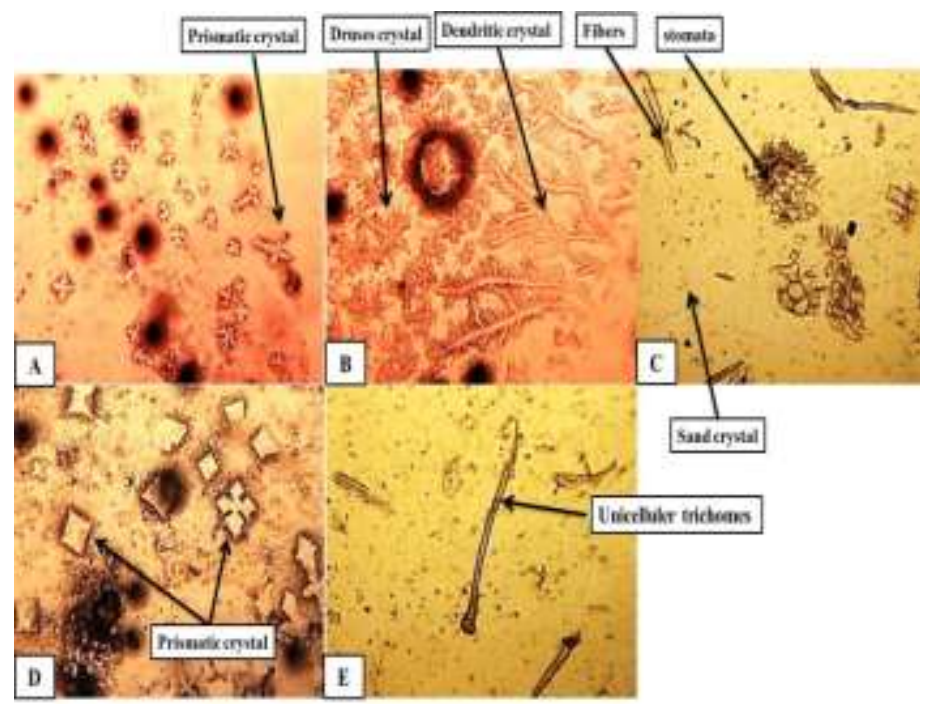

Fig. 6 Powder microscopy of Cordia myxa leaf (A: Prismatic crystal, B: Druses crystal and Dendritic crystal, C: fibers, stomata and sand crystal, D: Prismatic crystal, E: unicellular trichomes).

\section{ACKNOWLEDGMENTS}

We gratefully acknowledge the staff of the (Department of Biology, Faculty of Science, in The Central Service Lab.), in Iraq, for their technical support and laboratory assistance.

\section{REFERENCES}

[1] P. H. Davis, "Flora of Turkey and the East Aegean Islands",Vol 6. Edinburgh University Press, Edinburgh, 1978

[2] E.F.; E. F. Matias, M. K. Alves, V. R. Silva, H. D. Carvalho and J. G. Coutinho, " The genus Cordia: botanists, ethno, chemical and pharmacological aspects". Revista Brasileira de Farmacognosia, 2015, 25: 542-552. doi.org/10.1016/j.bjp.2015.05.012.

https://doi.org/10.1016/j.bjp.2015.05.012

[3] I.C.E. Barroso, F. d. Oliveira and D. M. Ciarelli. "Morphology of the dispersion unit ndgermination of Cordia sellowiana cham. and Cordia myxa" Bragantia, 2009, 68, 241-249.

https://doi.org/10.1590/S0006-87052009000100026

[4] K. S. Bawa, "Breeding systems of tree species of a lowland tropical community". Evolution, 1974, 28, 85-92. https://doi.org/10.2307/2407241

[5] M. Arrebola, M. Peterlin, D. Bastos, R. d. O. Rodrigues and P. d. O. Carvalho, "Estudodos componentes lipídicos das sementes de três espécies do gênero Cordia L.(Boraginaceae)". Rev. Bras. Farmacogn, 2004, 14, 57-65.

https://doi.org/10.1590/S0102-695X2004000100008

[6] N. Al-Musayeib, S. Perveen, I. Fatima, M. Nasir and A. Hussain." Antioxidant, anti-glycation and anti-inflammatory activities of phenolic constituents from Cordiasinensis". Molecules, 2011, 16, 10214-10226. https://doi.org/10.3390/molecules161210214

[7] M. Panghal, V. Kaushal, J. P. Yadav, "In vitro antimicrobial activity of tenmedicinal plants against clinical isolates of oral cancer cases". Ann. Clin. Micro-biol. Antimicrob., 2011,10, 1-11. https://doi.org/10.1186/1476-0711-10-21

[8] F.M. Oliveira, J.C. Diniz, F.A. Viana, S.A.S. Rocha and H.M. DaSilva-Junior,"Quantificac, ão por CLAE de naftoquinonas do extrato de raízes de Cordia leu-cocephala Moric". HOLOS, 20121, 41-48.

[9] S.A.S.d. Silva, M.d.F. Agra, J.F. Tavares, Cunha, E.V., J.M. BarbosaFilho and M.S.d. Silva, "Flavanones from aerial parts of Cordia globosa (Jacq.) Kunth, Boraginaceae". Rev. Bras. Farmacogn, 2010, 20, 682685. https://doi.org/10.1590/S0102-695X2010005000006

[10] S.P. Pimentel, G.E. Barrella, R.C.V. Casarin, F.R. Cirano, Casati, M.Z., Foglio, M.A.,Figueira, G.M., Ribeiro, F.V., "Protective effect of topical Cordia verbenaceain a rat periodontitis model: immune-inflammatory, antibacterial and morpho-metric assays". BMC Complement. Altern. Med., 2012, 12, 224.

https://doi.org/10.1186/1472-6882-12-224

[11] P. Bhattacharya, A. Saha,. Evaluation of reversible contraceptive potential ofCordia dichotoma leaves extract. Rev. Bras. Farmacogn., 2013, 23, 342-350. https://doi.org/10.1590/S0102-695X2013005000020

[12] M. Bayeux, A. Fernandes, M. Foglio and J. Carvalho,. "Evaluation of the antiede-matogenic activity of artemetin isolated from Cordia curassavica", DC. Braz. J. Med. Biol. Res., 2002, 35, 1229-1232. https://doi.org/10.1590/S0100-879X2002001000017

[13] A.A. Dasti, T.Z. Bokhari, S.A. Malik and R. Akhtar "Epidermal morphology in some members of family Boraginaceae in Baluchistan". Asian J Plant Sci, 2003,2:42-47

https://doi.org/10.3923/ajps.2003.42.47

[14] R. Binzet and ÖE Açkin "The morphological and anatomical properties of two endemicOnosma species (O. intertextum and O. sieheanum)". Acta Bot Hung, 2009,51:1-9.

https://doi.org/10.1556/ABot.51.2009.1-2.1

[15] E.E.A.D. Tölke, J.I.M. De Melo and S.M. Carmello-Guerreiro, "Leaf anatomy with emphasis on separation of two species of Varronia P.Br. (Cordiaceae) of the Brazilian semi-arid region.” Braz. J. Bot), 2013, 36 : 189. https://doi.org/10.1007/s40415-013-0022-5

[16] M. N. AL-Aani, M. A. AL-Hadeethi, A.K. AL-Anbari and D. A. AbdAL-Gabar. " Description Anatomical study of Dodonaea viscosa in Iraq". Journal of Biology, Agriculture and Healthcare, 2016, 6, (10): 
119-123. www.iiste.org . ISSN 2224-3208 (Paper) ISSN 2225-093X (Online)

[17] A. Ahmed and A. Kordofani "Morphological and anatomical studies of Cordia abyssinica R.Br. and Cordia sinensis Lam. (Boraginaceae) in Sudan". J. Chem. Pharm. Res., 2012, 4(10):4582-4588.

[18] A. Thammathaworn, "Handbook by paraffin method. Department of biology" Faculty of science, Khon Kaen Universality, Thailand. 1996

[19] S. Edwin, S. B. Joshi and D. C. Jain, " Comparative pharmacognostic studies on root powder of Plumbago zeylanica and Plumbago rosea". Indian J Nat Prod., 2008, 24(2):27-29.

[20] H.J. Arnott, F.G.E. Pautard and H. Steinfink "Structure of calcium oxalate monohydrate" . Nature, 1965, 208, 1197-1198. https://doi.org/10.1038/2081197b0

[21] A. Frey-Wyssling "Crystallography of the two hydrates of crystalline calcium oxalate in plants". Am. J. Bot., 1981, 68, 130-141.

https://doi.org/10.2307/2443000 